\title{
腦脊髓液壓上昇ガ前庭性眼球震燙二及ボス 影響二就于（實驗的研究）
}

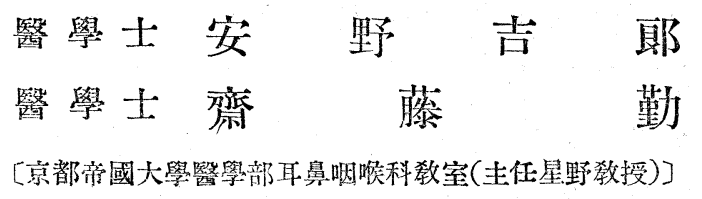

\begin{tabular}{|c|c|c|c|c|}
\hline & & 为 & & \\
\hline 1 & 綨 & 言 & 4. & 總括及ピ考察 \\
\hline 2. & & 法 & 5. & 結 \\
\hline 3. & 實 & 錄 & 6. & 歐 文自抄 \\
\hline
\end{tabular}

1. 悢

言

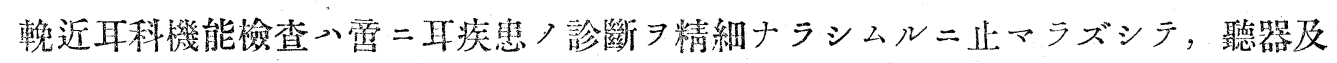

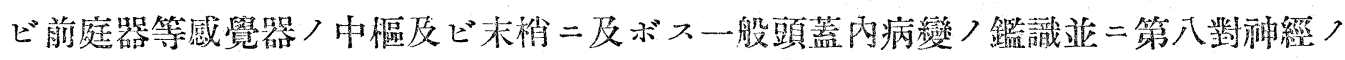

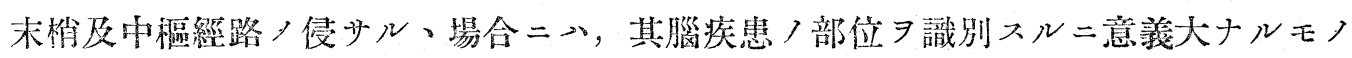
$ア ル ニ$ 到レリ。而シテ頭蓋內疾患ニシラ聽器, 前庭器及ビ其中慪二及ボス影響ク中

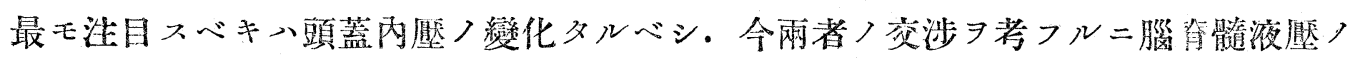

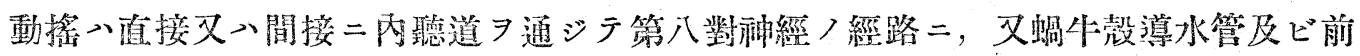
庭導水管 ヨ通シテ末梢器官二影響 ヨ及ボスベシ, 就中一般頭蓋內疾病二際シテ甚ダ

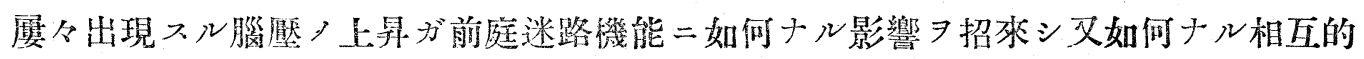

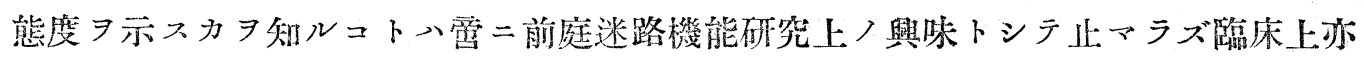
頌儿緊要事ナリトス。”

然ルニ這般つ問題ニ關スル文献ヨ按ズル二頭蓋內壓ノ艺進七ル場合二其前庭迷路 機能ニ及ボス影響ニ關シテハ一二ノ粗漏ナル臨床的觀察例アルモ，一ッハ唯腦壓上

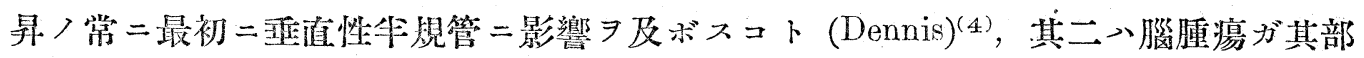

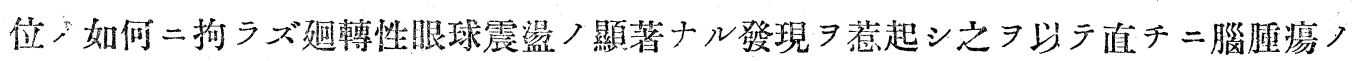
一徽候下認ムル (Guttich $)^{(6,7)}$ ノ類二過ギズ。

他方二腦春髓液壓上昇ノ前庭機能二及ボス影響ニ就デ實驗的研究二至テン未ダ 何人モ手习染メショトナク該方面ノ吾人ノ知識》全ク欠如ス。之レ余等ガ本問題ノ 實驗 企圖七ル所以ナリ。 


\section{2. 實 驗 方 法}

實驗動物二八體重三瓦內外,强大ナル家鬼ニシラ豫メ耳鏡檢查ニョリ中耳二病變 ナク更二迴轉及ビ冷温刺戟ニヨリ正常ナル迷路反應

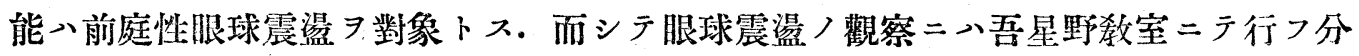
離眼筋ノ運動曲線ノ描畫法

腦脊鹃液壓上昇及ビ其描畫法.

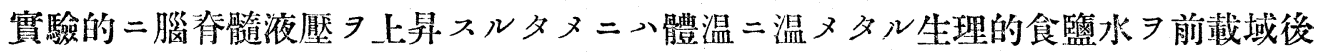
頭膜 (Membr. atlanto-occipitalis) ヨリ第四腦室中二注入久。而シテ此目的ノ䈆並二 更ニ之ヨ描畫的ニ表現センガ篇余等ハーッノカニユーレヨ製作セリ。(下圖參照)

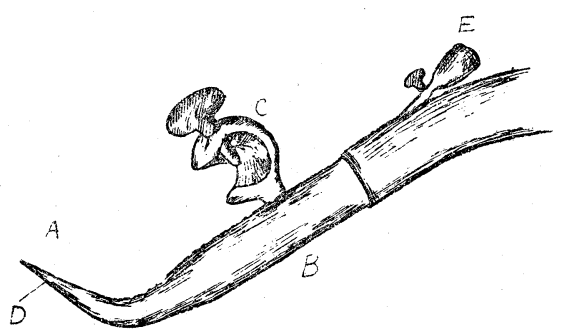

嘴部 (A) 管體 (B) 及之ヨ支柱二固定スベキクレムヌ (C) ヨリナル長少約 5 耀. 太少4癿ナリ・主要點・嘴部ニシテ管體ニ對シ約 130 度ノ鈍角

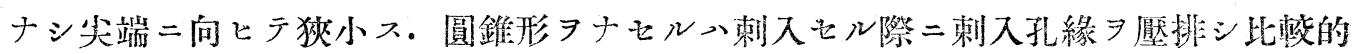

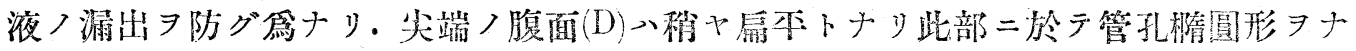

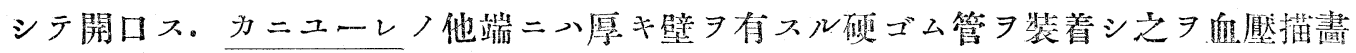
用水銀マノメーター二連結ス。而シテカニユーレ管端二近ク讙謨管壁ヨリ管膑中へ 括栓ヨ有スル太丰注射釬 $(\mathrm{E})$ ア豫メ剌入シ置クベシ。使用法ハ先ヅ水銀マノメータ一

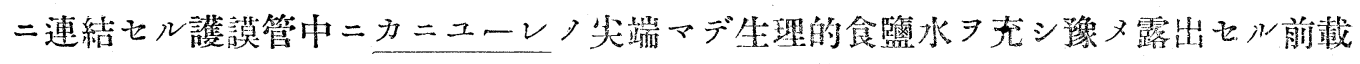
域㣪顽膜, 可及的下方二於テ樞軸/背面二接スル如クカニニーレヨ刺入ス。之ヨ刺 入スルヤ值テ二尖端 ヨ防グ、斯クシテ嘴部ノ約三分ノ二ヨ刺入シタル位置ニ於テカニューレヨ支桂二固 定入。

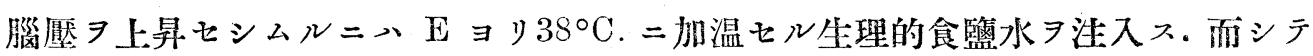
上昇七ル腦壓ハ水銀アノメーターノ浮標二連結セル書槙ニヨリ描畵セシム。

斯ノ如ク實驗的二上昇七シメタル腦壓ノ變化つ經過卜眼球震盪曲線卜ヨ時的二曲 線ニ現ハシテ其相互つ關係习觀察ス。 
向實驗二必要ナル耳及迷路ノ諸手術例之迷路冷温刺戟二要スル外疆道及中耳二施

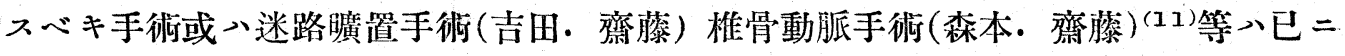
數次吾敎室員ノ業績中ニ記載サレタル所ナルョ以テ重ネテ記述ノ煩ヨ省ク。

\section{3. 實 驗 記 錄}

本研究入大正十五年一月始ヨリ同三月枺二亘り營編セルモノニシテ家鬼二十五頭 ヨ使用セリ。

\section{1. 特發性眼球震盪二對スル腦歇上暴ノ影響}

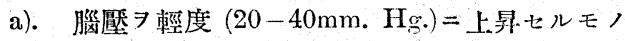

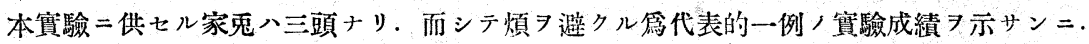

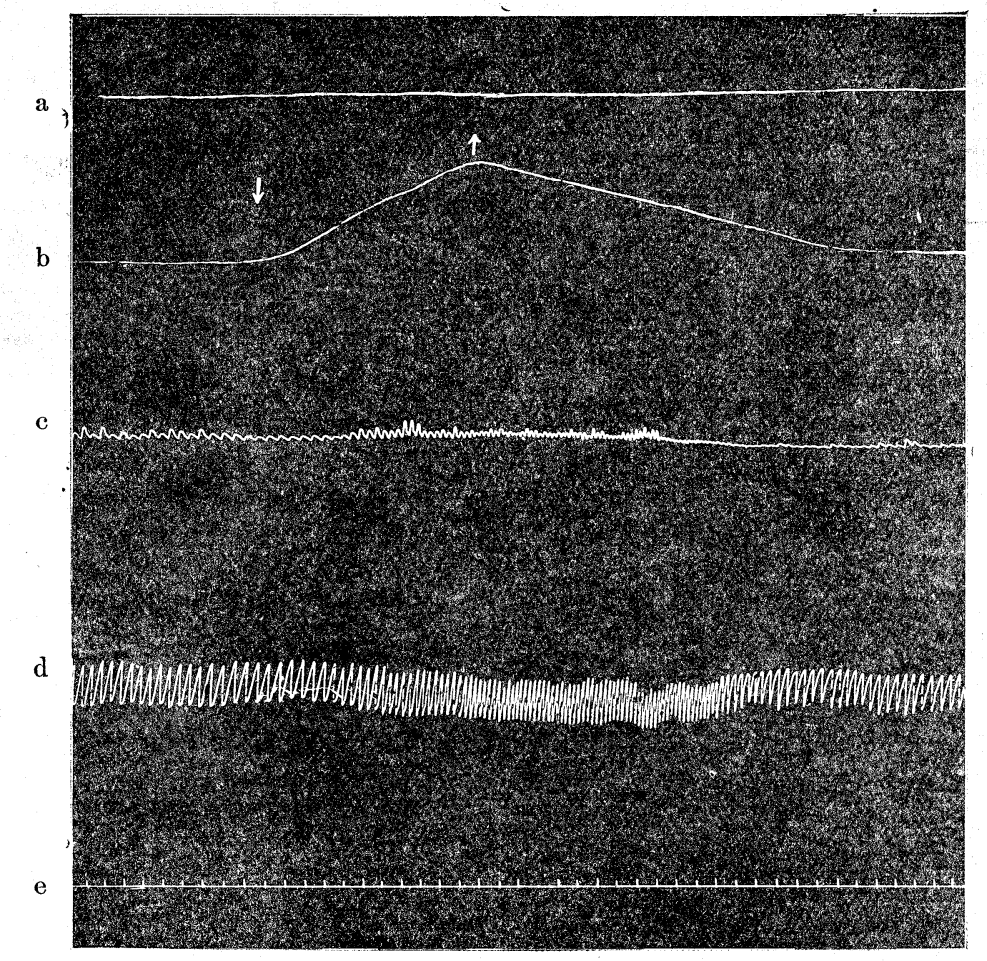

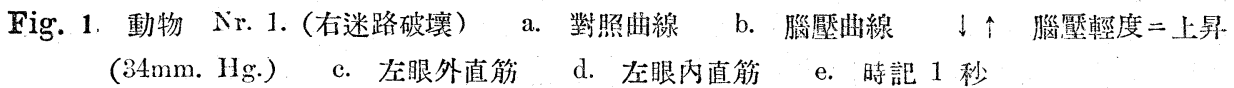

動物 Nr. 1. $3000 \mathrm{~g}$ 令

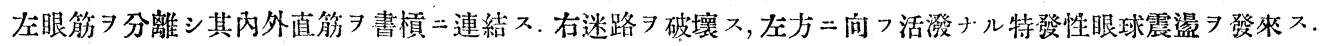

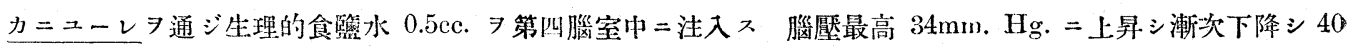
秒後正常 $=$ 復 7 . 


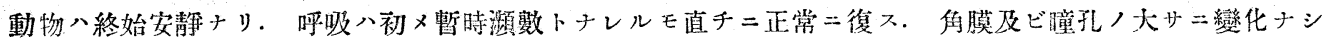

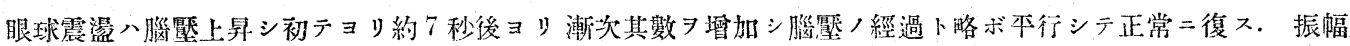
ニ八著シキ變化ナシシ（曲線1.參照）他ノ二頭ノ家鬼ニ於テモ火體同樣ノ成績ヨ得タシ。

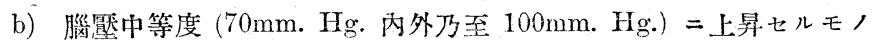
本實驗二偨セル家弃三頭ナリ．今其代表的實驗例 示サンニ。

a
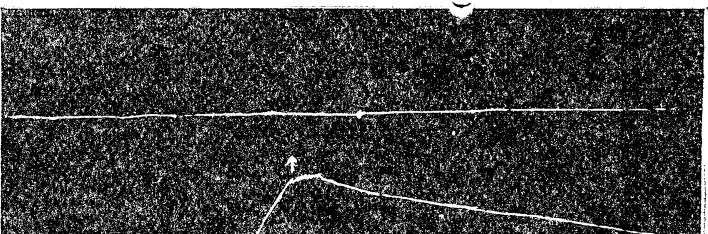

b
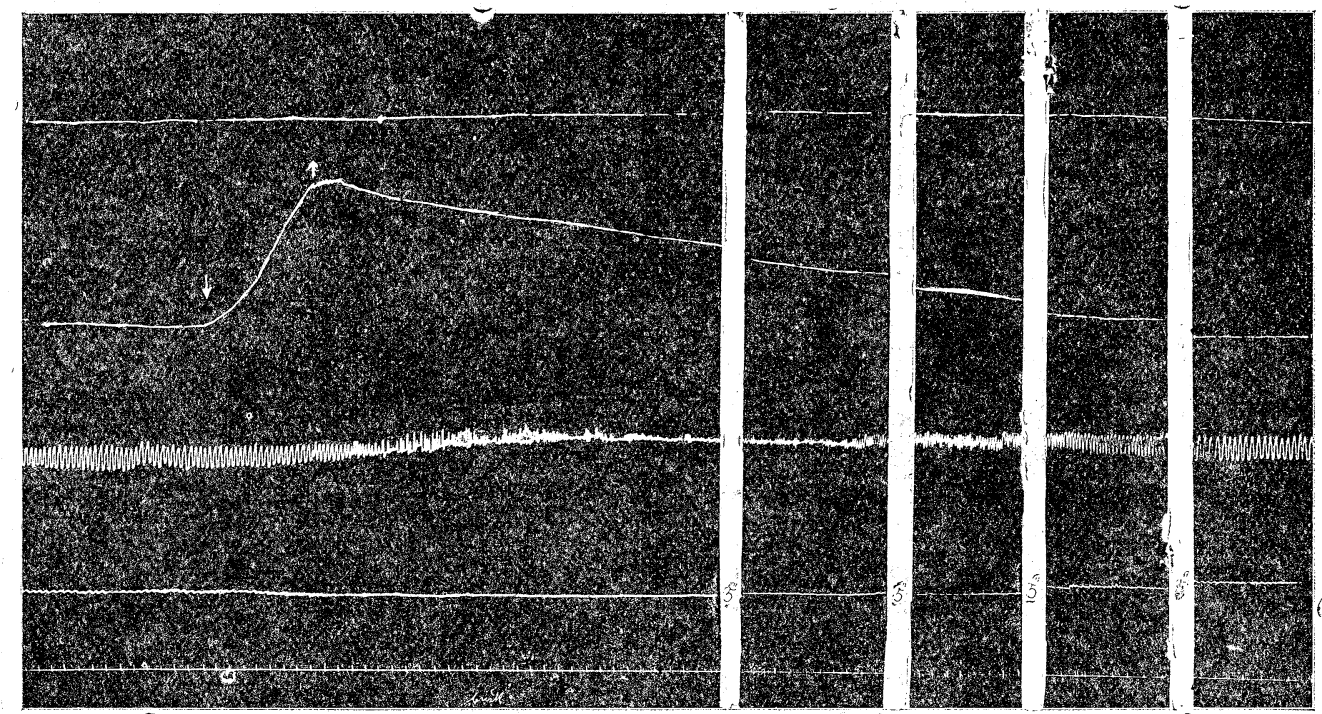

Fig. 2. 路物 Nr 2. (右迷路破壤)

a. 對照满線

b. 腅檿曲線

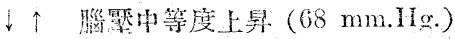
c. 庄眼㐫直筋
d. 庄跟外㨁筋
e. 時訅 1 秒

動物 $\mathrm{Nr}, 2.2800 \mathrm{~g} \quad \hat{\mathrm{s}}$

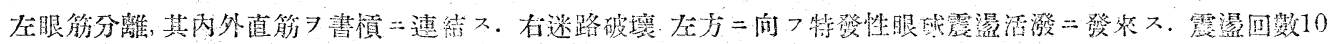

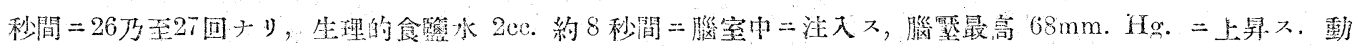

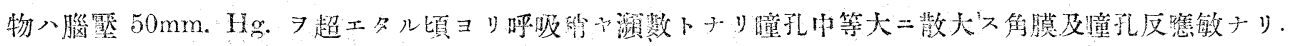

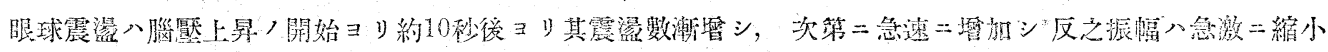

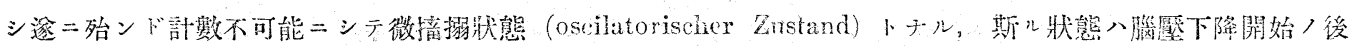

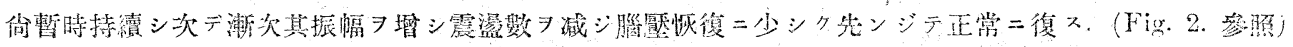

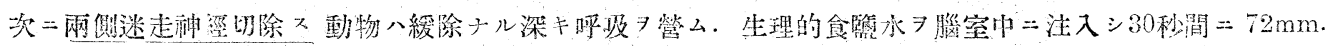

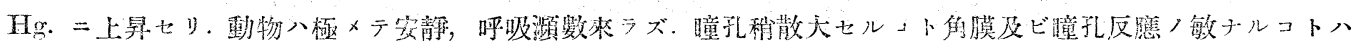
期回卜同樈ナリ。

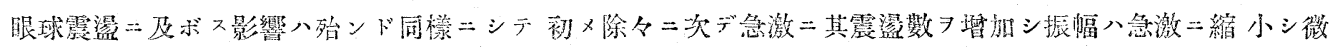

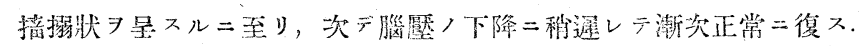

他ノ二頭, 實驗ニ於テモ殆ンド同樣ノ成績ヨ得タリ。

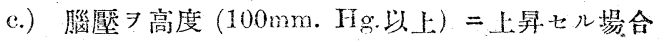

本實驗二供七几家兔ハ總テ四頭ナリ。其中代表的二實驗例ヨ示サンニ

動物 Nr. 7· $3000 \mathrm{~g}$ 令 
左眼筋分離，內外直筋 7 書槙 $=$ 連結

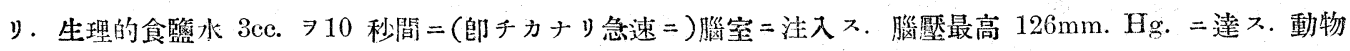
八呼吸塞迫. 不安八極メテ短時間二經過シ次デ却テ安静トナリ呼吸又緩徐トナル。噇孔ハ初メ八散大緒小不 定ナリシモ遂二極度二散大スルニ至ル、瞳孔，對光反隹八少消尖スルニ至ラズ．笛膜反射八殆シト證明ジ得ズ。

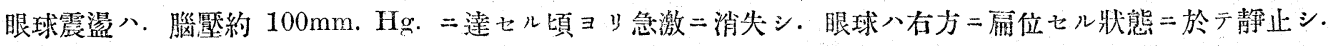

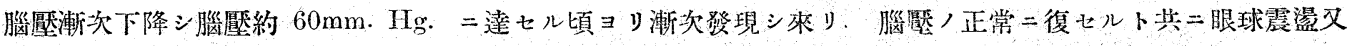
恢復七り. (Fig. 3 參照)

a

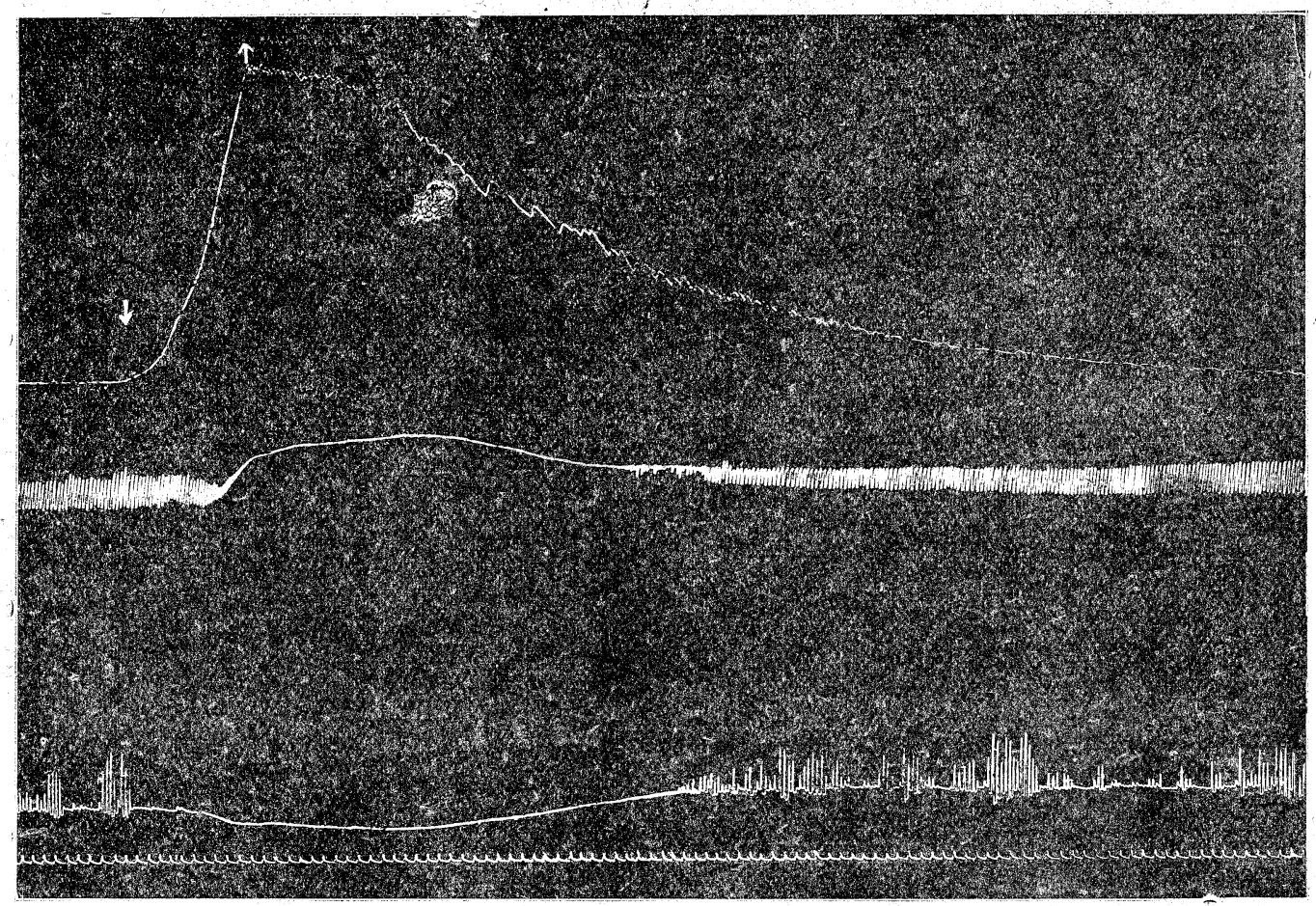

Fig 3. 動物 No. 1. (右迷路破壃) $\downarrow \uparrow \quad$ 䏩壓高度上鼠 $(126 \mathrm{~mm} \cdot \mathrm{Hg}$.) a. 對照曲線

c. 左眼外直筋 b. 腦㯺曲線

a. 左眼外直箭

e. 時訅 1 秒

動物 $\mathrm{Nr} .33200 \mathrm{~g}$ ～㝏

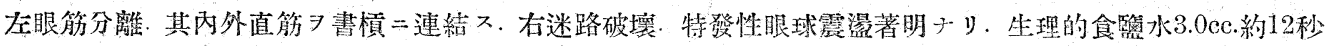

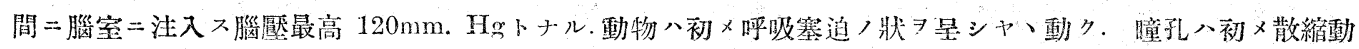

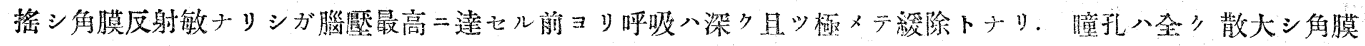

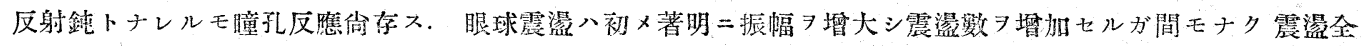

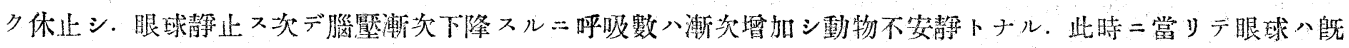

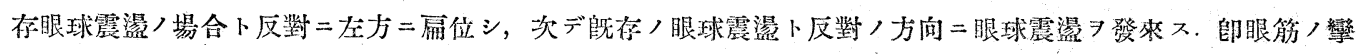

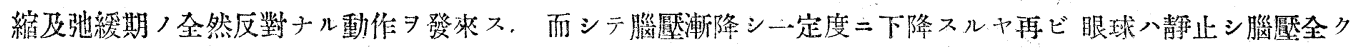

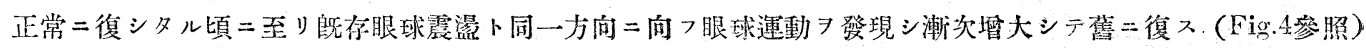

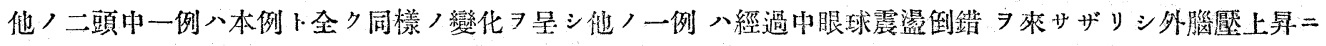


ヨル眼球震燙ノ影響八前例ト全ク同樣ナリ。

\section{腦へノ血行 シー時的ニ杜絕セルモノシメタルニ就キデ.}

本實驗二供セル家鬼二頭ナリ。其代表的例トシテ腦涯中等度二上昇セルモノノ實驗例フ示サン。

a

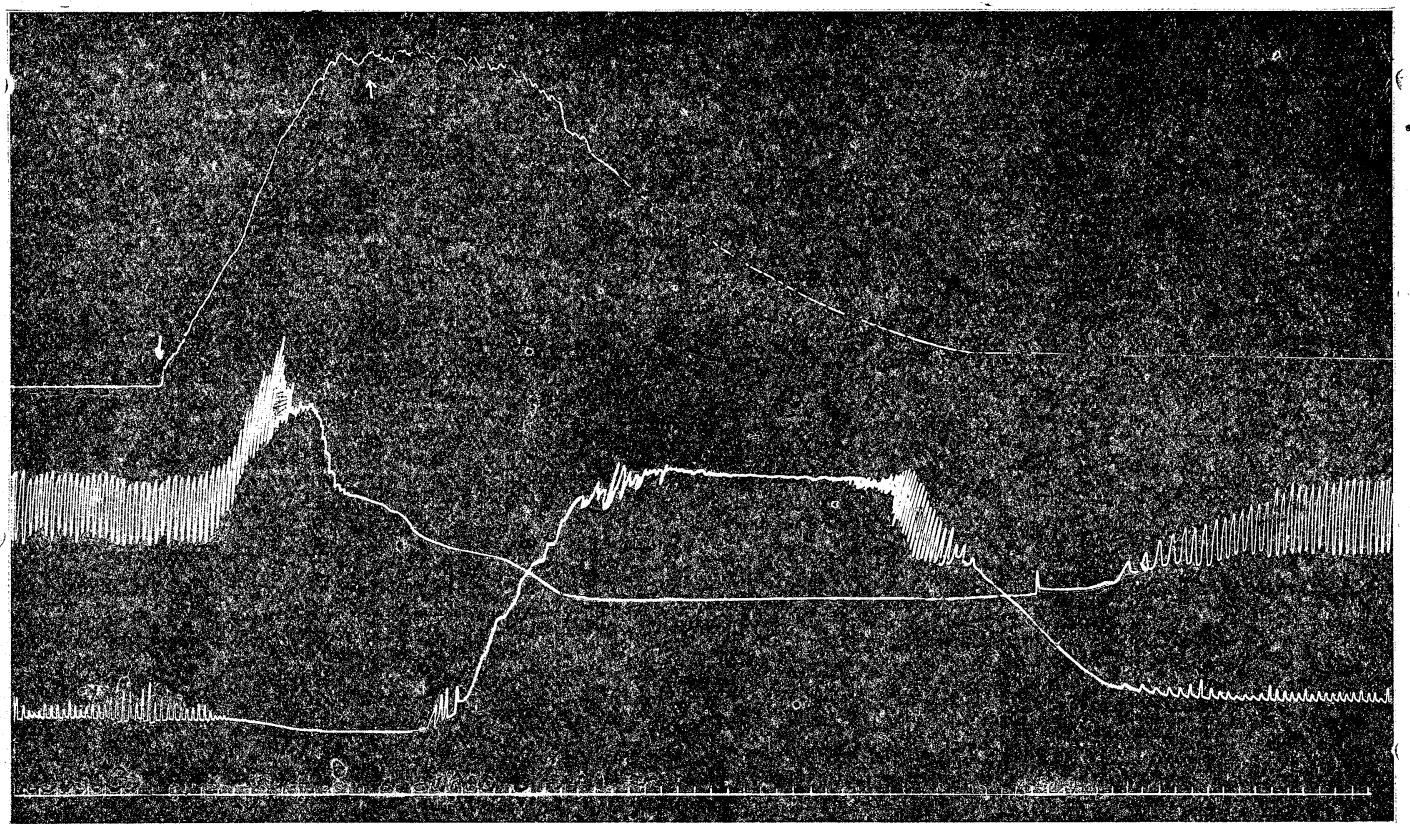

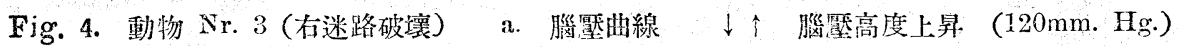
b. 左眼內直筋
c. 左眼外直筋
d. 時訅 1 秒
經過中眼球震䕄倒錯 7 呈セリ。

動物 Nr. $92150 \mathrm{~g}$ 占

右眼筋分離. 内外直筋 7 書槙二連結ス. 左迷路破壞. 特發性眼球震渾著明ナリ.

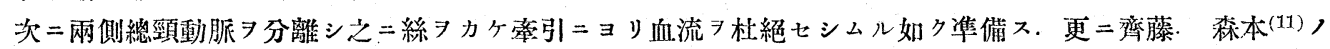

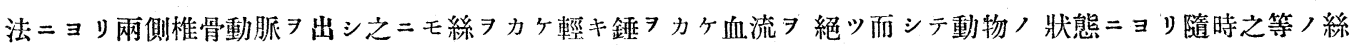

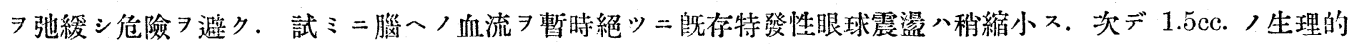

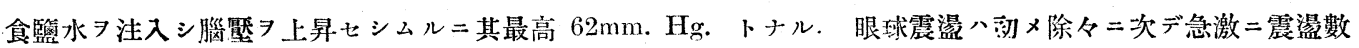

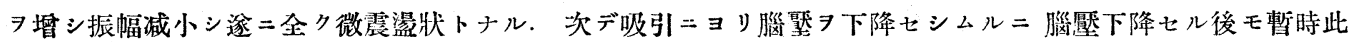
狀態 7 持續セル後漸次恢復 $ᄌ$.

\section{2. 中樞代償性眼球震湯二對 スル腦堅上暴ノ影響二就テ。}

a) 腦壓习輕度及中等度二上昇七儿場合.

本實驗二供セル家鬼二頭ナリ。・ノ一例ヨ示サンニ。

動物 Nr. 12. 우 $2800 \mathrm{~g}$.

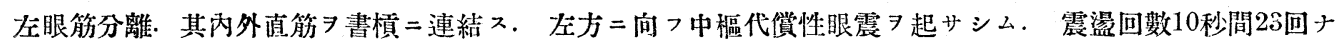




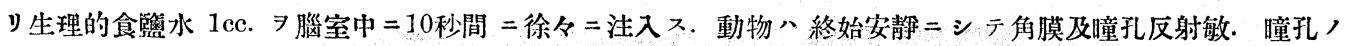

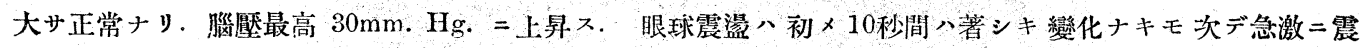

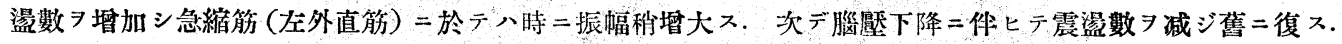
(Fig. 5 參照)

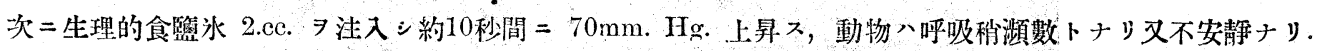

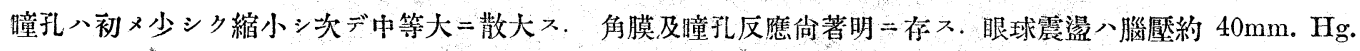

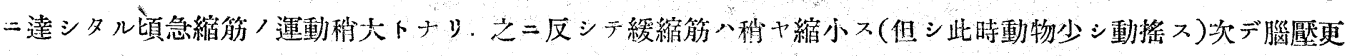

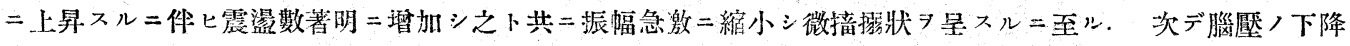

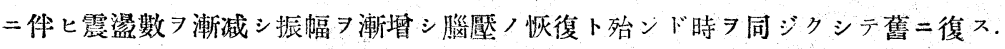

a
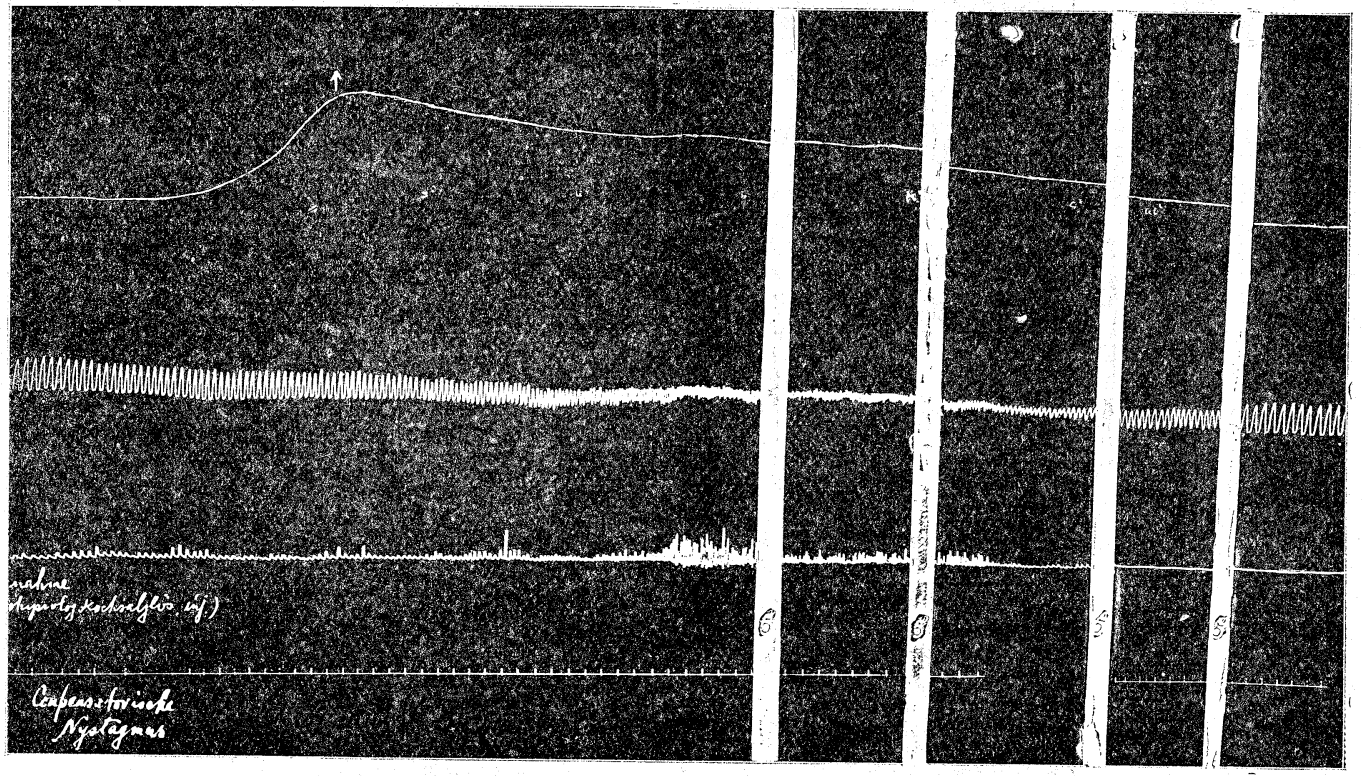

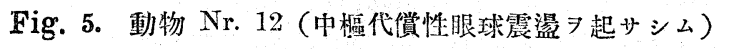

a. 腦壓曲楾

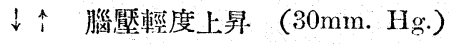
b. 左眼內直筋
c. 左眼外直筋
d. 時訅 1 秒

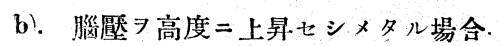

本實驗ニ供セル家鬼一頭ナリソノ實驗例 ヨ示サンニ.

動物 Nr. 1. 个 $2650 \mathrm{~g}$

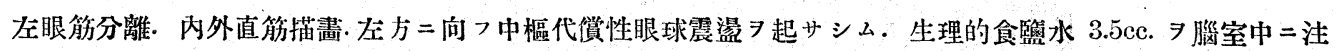

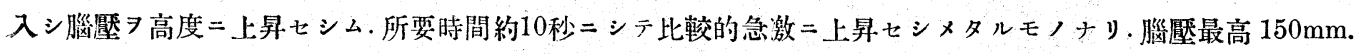

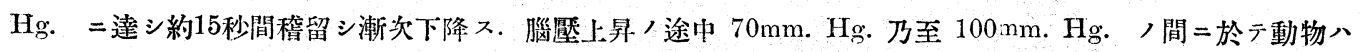
呼吸塞迫シ不安静トナル。此時瞳孔、散縮一定セズ角膜反射ハ過敏ナリ．腦壓 $100 \mathrm{~mm}$. Hg. ヨ超エタル後八 動物却ツテ安静トナリ呼吸ハ深ク且ツ緩除トナル，而シテ眼球震燙ハ初メ腦壓中等度二上昇セル場合 二八暫 時震滥數 反應僅カ二存ス. 眼球震湦全ク消失シ眼球八偏位セルマ、静止ス。然ル二腦壓漸次下降シ初ムルヤ䤧孔稍縮 
a

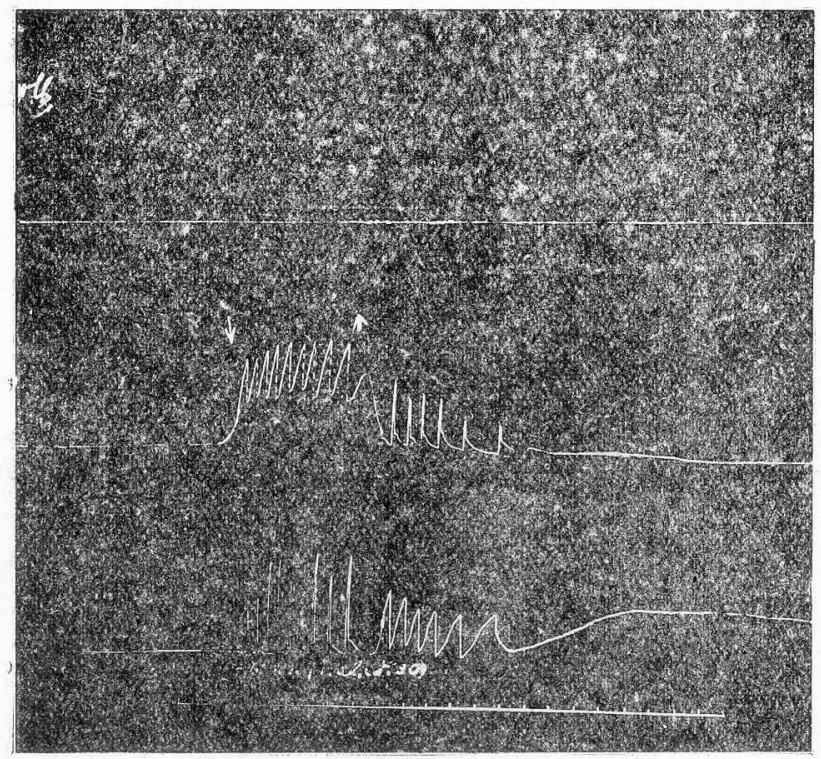

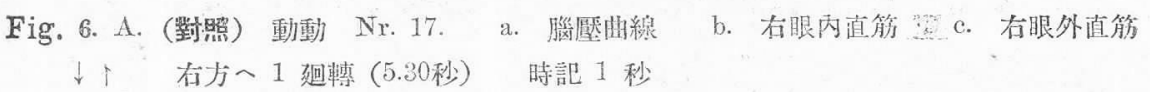

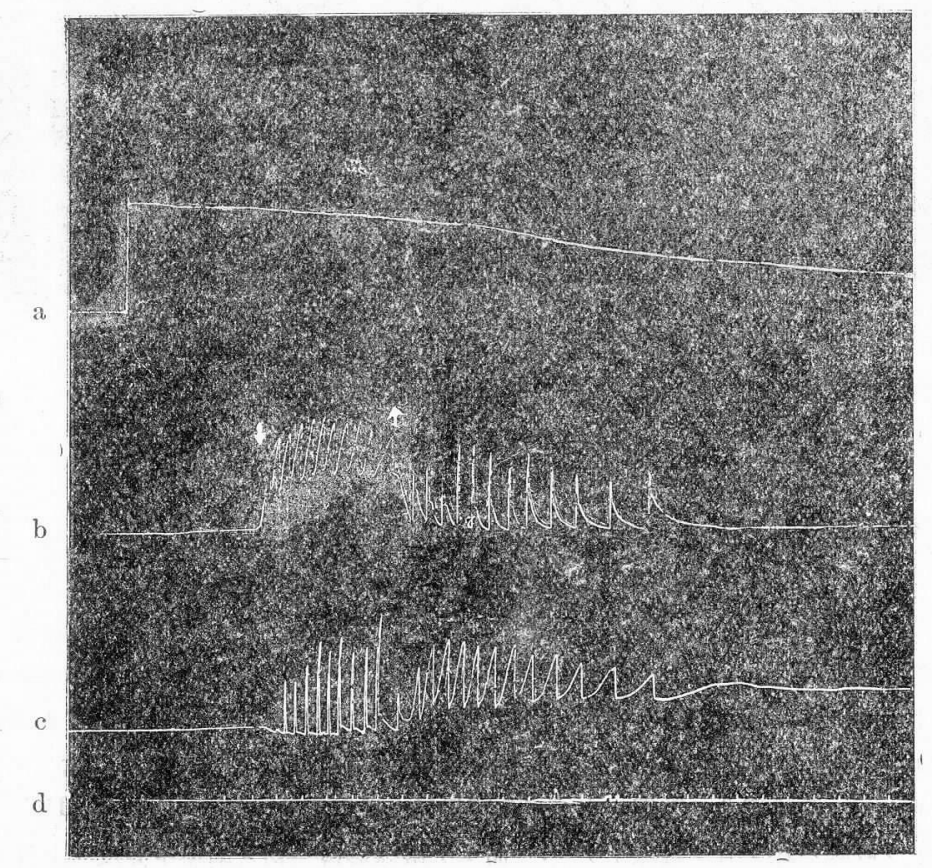

Fig 6. B. 動物 Nr. 17. a. 腦崖曲線 b. 存眼內直筋 c. 右眼外直筋

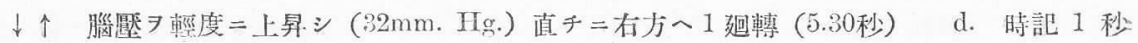




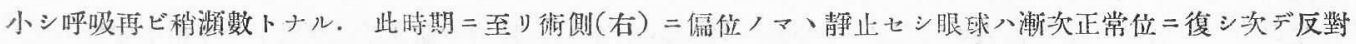

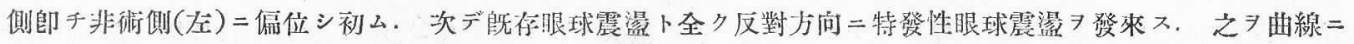

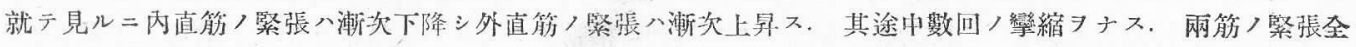

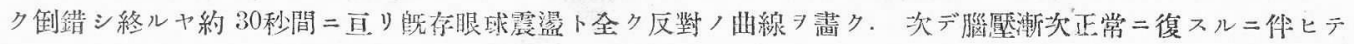

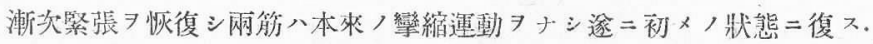

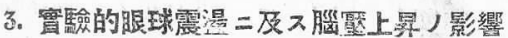

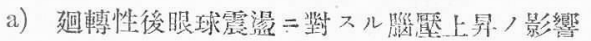

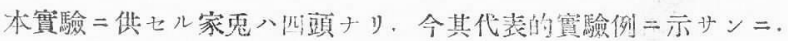

\section{動物 Nr. 17 . 우 $2500 \mathrm{~g}$}

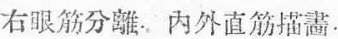

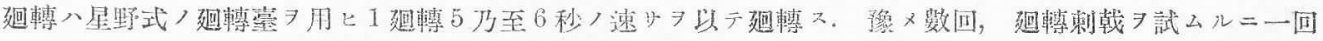

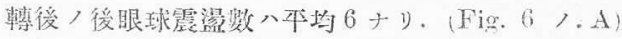

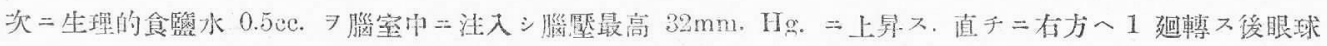

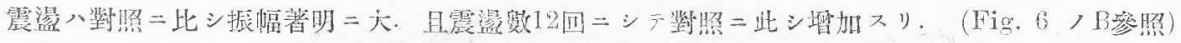

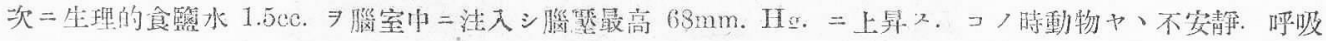

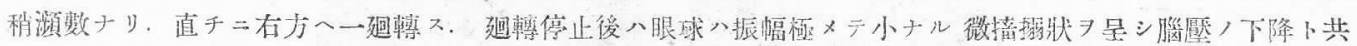

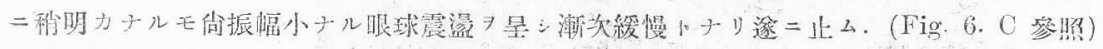

a

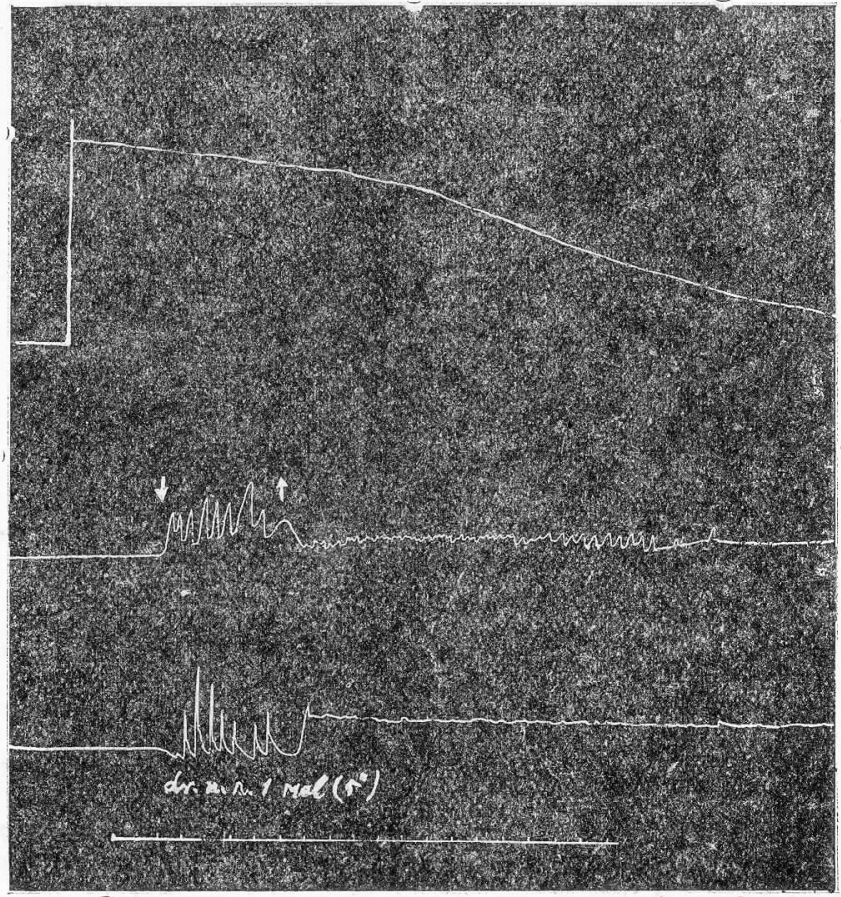

Fig. 6. C. 動物 Nr. 17. a. 腦畲曲線 b. 存眼內直筋 c. 存眼外直筋

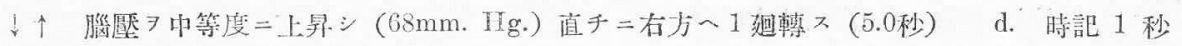




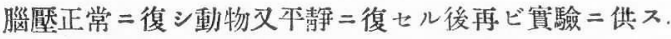

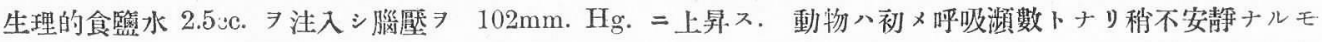

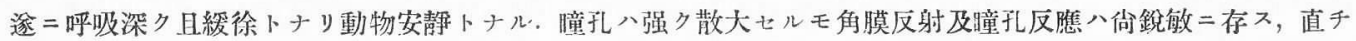
二右方へ一迴轉スル二迴轉停止後眼球八微小ナル一二回/揞動 ヨナシタル後眼球八右方二著明ナル府位 ス而シテテ眼球震湦ハ遂二發來セズ.

次二腦壓ヨ更二上昇シ $120 \mathrm{~mm}$. Hg. ニ至ラシム. 動沕ハ深大ナル呼吸ヨナシ安静ナリ瞳孔ハ極度二散大シ

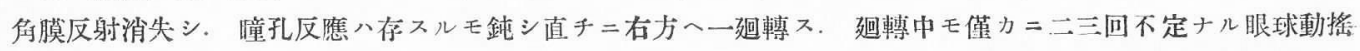
ヨナセルノミナリ，廻轉停止後八眼球反倠全クナシ。眼球八静止ス。 (Fig. 6. D參照)

他ノ二頭ノ動物ニ於テモ大體同樣ノ成績ヨ得タリ。

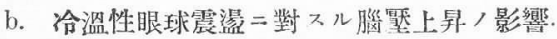

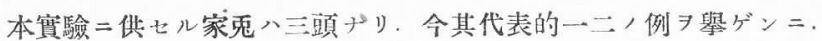

動物 Nr. 18. 占 $2700 \mathrm{~g}$ 右眼筋分離. 內外值筋描部

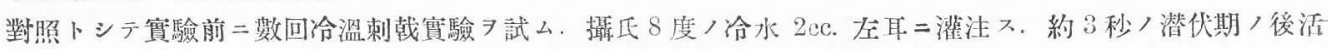

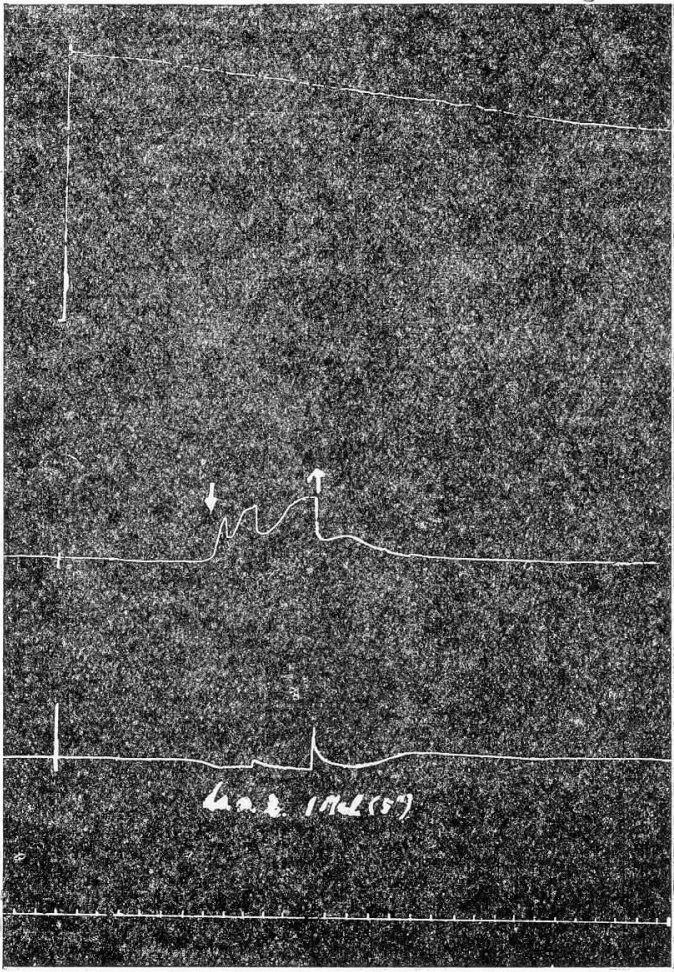

Fig。 6. D. 動物 Nr. 17. a 腦筑曲線 b. 右眼內直筋 C. 右眼外直筋

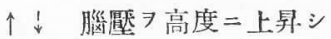
$(120 \mathrm{~mm} . \mathrm{H}$
g.) 值チニ右方へ 1 趈轉 $(5.0$ 秒)
d. 時記 1 秒

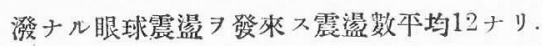




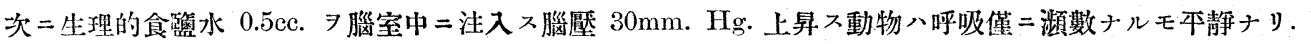

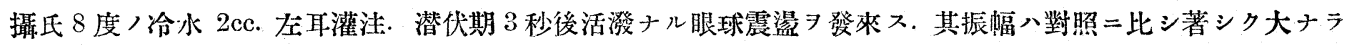

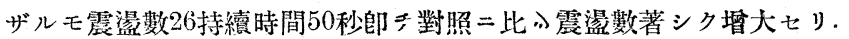

腦壓正常二復シ動物平静トナレル後生理的食悘水 20.cc. 腦室二注入ス.

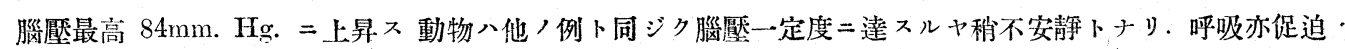

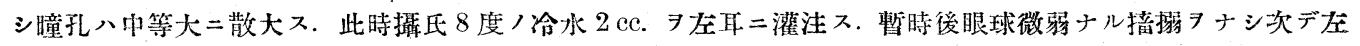
方二偏位七ルマ、静止 .

動物 Nr. 21. 우 2600g.

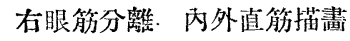

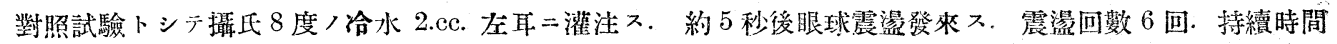

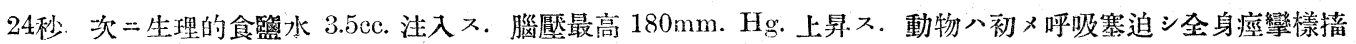
搦 ナシ. 眼球八數回. 左右二緩慢不規則ナル運動 フナス。此時值チ二攝氏 8 度ノ冷水 $2 . \mathrm{cc}$. ヨ左耳二灌注ス. 眼 ズ. 球震漫發來七

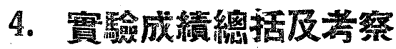

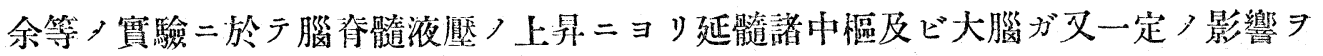
蒙ルベキハ勿論ナルべキラ以テ余等ハ實驗ノ對照トシテ實驗操作ノ許ス範圍二於テ 師チ呼吸狀態，角膜及朣孔反應，睡孔ノ大小，ソノ他動物ノ一般狀態等 今先ヅ之 7 概括セン二腦嶎上昇輕度 (20-40mm Hg.) ナル場合ハ呼吸平靜ナルカ，

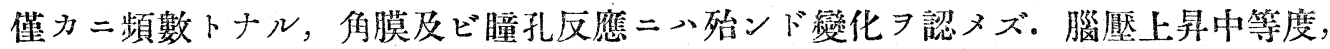
(ca.70-100mm. Hg.) ナル場合ハ呼吸可ナリ塞迫シ動物ハ本靜ナラズ朣孔反應及角膜

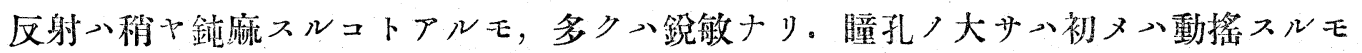
後多ク 小中等大二散大ス。

腦壓上暑高度 (ca. 100-150 mm. Hg.) ナル場合ハ初メ呼吸、促迫スルモ後却ツテ深 ク且緩徐トナリ動物又穴靜トナル，瞳孔ハ逐二極度二散大シ觕膜反射入鈍麻或ハ消

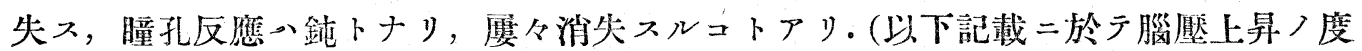
合入上記ノ範圍二於テセルモノト知ルベシ。）

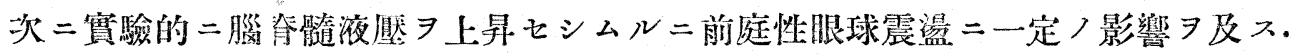
腦壓上昇輕度ナル場合二小其震湯數ノ增加

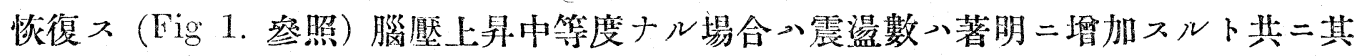
振幅、却ッテ漸次减少シ逐二微揞掦狀 (oscilatorisch) トナリ次デ腦壓ノ下降二件七 漸次正常二復入（Fig. 2 參照）腦盟上昇高度ナル場合二八時二其初メ二當リ一過性 二震盪數ノ增加 來スコトアルモ腦壓極度二上昇シ睡孔强ク散大シ觕膜反射消失シ 
瞳孔反應鈍麻乃至消失スルノ時期ニ至レバ眼球震燙ハ最早發來セズ．而シテ腦壓ノ 下降ト共二漸次恢復二向ヒ逐二正常二復スルラ見ル (Fig. 3 參照), 而シテ上昇ノ極 度二達シタル腦壓，下降セントスル一定時期二於テ巳存眼球震湦ト方向全ク正反對 ナル眼球震䔽郎チ眼球震盪倒錯 (Umschlag des Nystagmus; Arndt, de Kleijn, Versteegh (1)) ヨ隶スェトアリ. (Fig. 4 壆照)

腦二向フ全血流 影響ハ依然トシテ發現スルラ見ル。

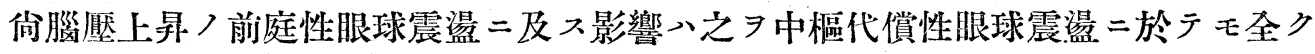
同樣二認又得. (Fig. 5 參照)

趈轉性若クハ冷温性刺㖪ニョル實驗的眼球震盪ニ對シテ腦壓上昇ノ影響》壓上昇 ノ程度ニョリ次ノ如ク觀察シ得. 腦壓上昇輕度ナル時ハ廻轉性後腿球震盪及ビ冷温 性眼球震盪入震蕰數

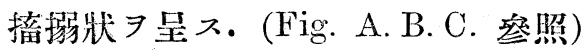

腦壓 二散大シ，角膜反射及曈孔反應倘存スル時期ニアリテハ眼球ハ少刺㦸側二向七テ扁 位 $尹$ 呈スルモ，瞳孔極度二散大シ角膜反射消失シ瞳孔反應僬鈍又心消失スル時期二 於テハ最早全ク前庭性眼球反應ヨ發隶スルコトナシ. (Fig. 6, D 參照)

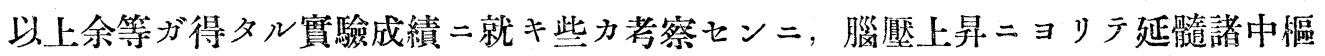

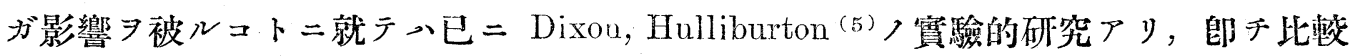

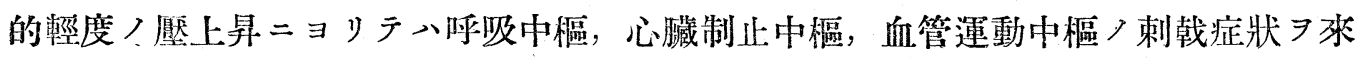
シ，高度二塺上昇ノ場合ハ呼吸中樞ハ先ジ麻瘟セラレ呼吸靜止スルモ他,二中樞ハ 活動シ血壓入極度二上昇シ次デ少時ノ後心臟制止中樞入麻愺もラル、モ血管運動中

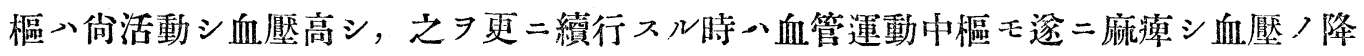
下ヨ見ルト云フ・螺良 ${ }^{(13)}$ モ亦之ヨ詳細二追試シ Dixon 等ノ言へル所ニ一致セル成 績ヨ得タリ・

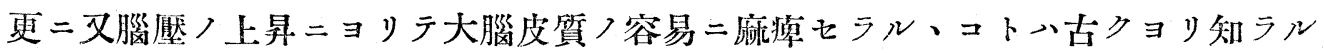
、所ニシテ Dalton, Howell, Budgett, Leonard(3)等八頭蓋腔內二買物

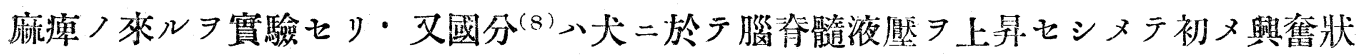

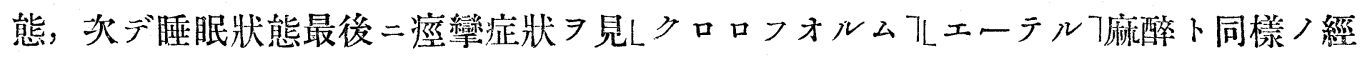
過ヨトルラ實驗セり。而シテ余等ガ實驗つ對照トシラ觀察セル，動物ノ呼吸狀態， 


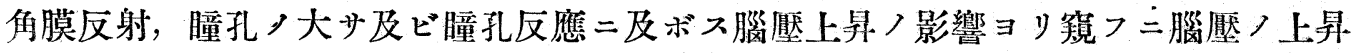
ガ其程度二從七延髓及ビ大腦二對シ略ボ前記諸家ノ云へルガ如ク影響スルモクト認 ムルョ得ベシ.

次二, 抑モ腦壓ガ前庭性眼球震盪二上來記述セル如キ影響ヨ與フル所ノ襲擊點 之ヨ何處二索ムべキャ. 腦壓上昇ガ內聽道二於ヶル第八對神經經路二影響ヨ及スべ キハ最モ思考シ易キ所ナリト踓モ同時二蝸牛殼導水管或入前庭導水管 迷路二其影響ヨ及スコトモ亦考一得ラル、所ナリ.彼ノWeber-Liel ${ }^{(16)}$ ガ內淋巴囊ノ

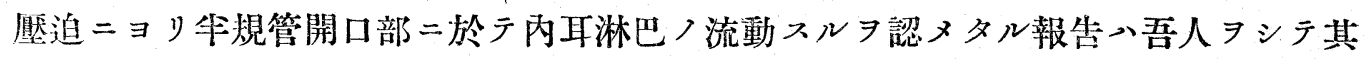
末梢性影響ノ存在 $ヨ$ 思ハシムルモノアリ。然レドモ此點二關シテー余等ハ何等末梢 迷路つ關與スルコトナキ代償性哏球震盪つ實驗ニョリテ腦嶎上昇ガ末梢迷路以外ノ

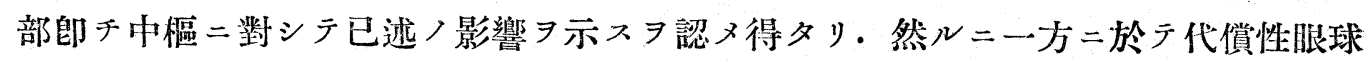
震盪入前庭性延䯝中嵒二於テ營マル、ノ確證アリ. (Spiegel u. Demetirades ${ }^{(12)}$ usw.) 又他方二於テ腦壓 延髓諸中樞ガ影響セラル、メDixon, Halliburton 及螺良等ノ實證セル所ナリ・余等

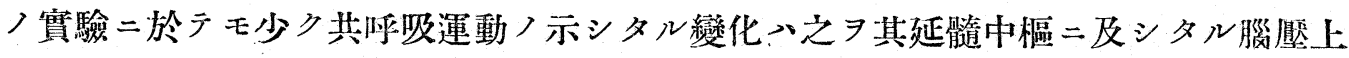
昇ノ影響卜認ムベキモノアリ。而シテ之ガ前庭性眼球震盪ノ變化ノ强弱卜能ク併行 スルヨ認メ得タル等ノ成績ヨリシテえヨ觀レバ腦壓上昇ノ前庭性眼球震璗二影響 辫ス攻擊點》前庭性延髓中樞二存スルラ思考七シム。

次二之ヨ中愊性ノモノナリトセバ中慪ニ於ケル如何ナル機制二依ルモノナルカ, 此際前庭性眼球震盪二影響习及ボス因子ハ元ョリーニシテ足ラザルベシト踓モ就中 腦壓上昇二因ル中懆种經系ノ貧血狀態 經へノ全血流ア一時全ク杜絕セシヌ以テ貧血ヨ起サシメタル余等ノ實驗二於テ依然 トシテ腦壓上昇ノ影響ヨ全ク同樣二證明ャルョ以テ除外シ得.

\section{5 結詥}

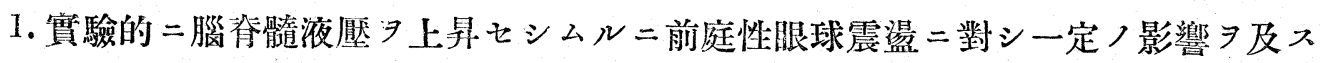

2. 腦壓上显輕度 (20-40mm. Ho.) ナル場合ニ八前庭性眼球震盪ノ震盪數ノ增加 以テ圭ナル變化トシ，腦壓ノ下降二伴ヒ終二正常二復ス。

3. 腦娾上昇中等度 (ca. 70-100mm. Hg.) ナル場合二八其震盪數ノ著明ナル增加二

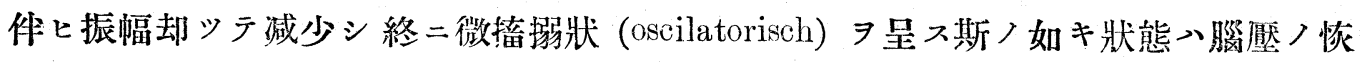
復卜共二正常二復ス。 
4. 腦壓上萛高度 (ca.100-150mm. Hg.) ナル埸合二メ, 壓上昇ノ初メ二當リ時二一

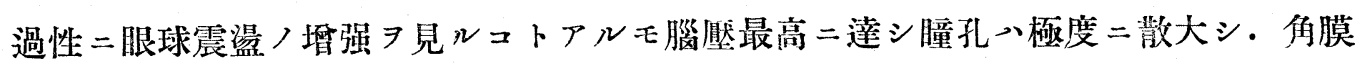
反射消失シ，瞳孔反應鈍麻若クハ消失スル時期二於テい前庭性眼球震盪入全然發來 七ズ. 腦壓漸㳄下降スルニ從ッテ前庭性哏球震蕰入已存ノ狀態二復ス. 而シテ, 極 度二上昇七ル腦壓ノ下降七ントスル一定時期二於テ眼球震盪方向ノ倒錯 $ヨ$ 來スコト アリ。

5.腦二向フ全血行 ハ低然トシテ發現ス。

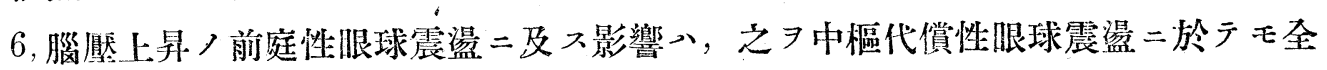
ク同樣二認又得.

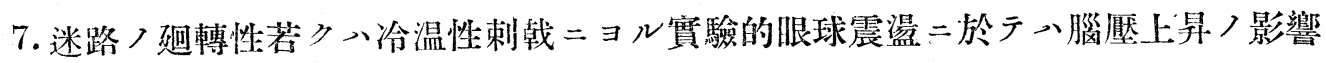
八壓上昇ノ程度ニヨリ次ノ如ク觀察シ得.

8. 腦壓上昇輕度若クハ中等度ナル場合二八迴轉性後眼球震盪及冷温性眼球震盪ノ

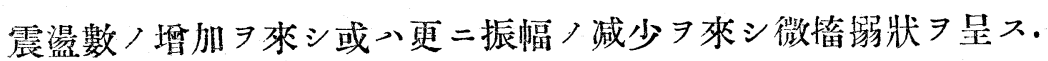

9. 腦壓 高度二上昇セシタテ冷温性若ク八迴轉性後眼球震盪 中等大二敬大シ，角膜反射及瞳孔反應尚存スル時期二於テ・眼球ハ少刺战側二扁位 ヨ呈スルモ，睡孔極度二敬大シ，角膜反射消失シ，瞳孔反應迤鈍又心消失スル時期 二於テハ最早全ク前庭性眼球反應ヨ發來スルェトナシ。

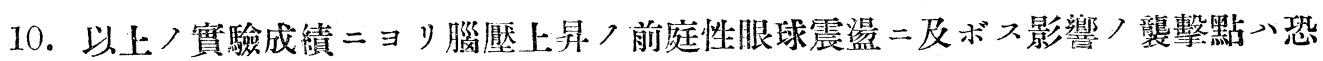
ク前庭性㢟䯣中樞ナルベシ。

本實驗入吾ガ星野教室二於テ帝國學士院學划研究費補助ノ下ニ行ヒシモノナリ記 シテ謝意ヨ表ス。

\section{Literature.}

1) Arndt, de Kléijn, Versteegh ; Pharmakolog. Untersuchungen ïber Wirkungen des Panitrins auf die isolie:ten Augenmuskeln des Kaninchens. Arch. f. Ohren-Nasen u. Kellkopfhei kunde. Bd. 114. 3/4 Ht. 1926.

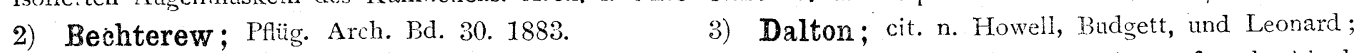
Journ. Physiolog. Bd. 16 1893. $\quad$ 4) Dennis; The practical diagnost. value. usw. Ann. of otol. rhinol. u. laryngology. Bd. 32. 1923. Ref. Zentralblatt f. Hals- Nasen und Ohrenheilkunde. Bd. 4. 1924.

Dixon u. Halliburton; The general cffects of increasing the ze:ebrospinal pressure. Journ. of physiology. Vol. 48. $\begin{array}{lr}\text { Bd. 12. 1924. } & \text { 7) Derselbe: Die intrakranielle Komplikatio } \\ \text { der Chirurgie des Ohres urd der oberen Luftwe } & \text { e. Leipzig. } 1924 .\end{array}$

6) Güttich; Über diagnost. Schwierigkeiten bei Hirnkranken. Zeitschr. f. Laryngologie.

8) 國分; 一新麻西卒法 (物理學的全 身麻醉) 中外整事新報 1023 虎.

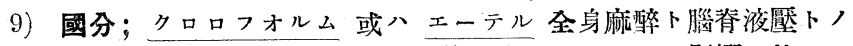

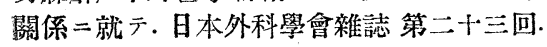

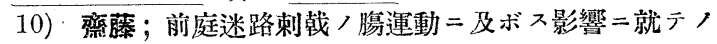


實驗的研究 第一及 第二回報告 耳鼻咽喉科臨床 第十九谷 第一號 及 第三號. 大正十四年 乃至 十五年.

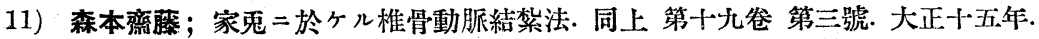

12) Spiegel u.

Démétriades; Die zentrale Kompensation des Labyrinthverlustes. PAïg. Arch. Bd. 210. 1/2 Ht. 1925.

13) Tsubura, S.; The effects of increased intracranial pressures on the medullary centeres. Brit. Journ. of experiment. patholng. Vol. 5. 1924.

14）吉田；麻醉時二於ヶ儿前庭性眼球震温/一異型二於

テ 北越醫學會雜誌 第三十九年 第五號 大正十三年. 115$)$ Weber- Liel ; Experimenteller Nachweis einer freien Kommunikationen der endolymphatischen und perilymphatischen Räume des menschlichen Ohrlabyrinthes mit extralabyrintischen intrakraniellen Räımen. Arch. f. Patholog. Anatomie, Physiologie u. Jslin. Medizin. Bd. 77. 1879.

\title{
Über deu Eiufluss der Drucksteigerung der zerebrospiualeu Flüssigkeit auf die vestibuläreu Nystagmus
}

\author{
Von \\ Dr. K. Yasuno u. Dr. I. Saito \\ (Aus der oto-rhius u. laryngsỉogischen klinik der Kaiserlichen Universität za Kyoto. \\ Director. Prof. T. Hosmivo.)
}

Durch die experimentelle Drucksteigerung der zerebrospinalen Flüssigkeit mit einem bestimmten Apparatus wurde deren Einfluss auf den vestibuläre Nystagmus graphisch dargestellt, und die folgende Schlüsse herausgezogen.

1. Der Druck des zerebrospinalen Flüssigkeit steht mit iem vestibuläre Nystagmus in einer intimen Beziehung.

2. Die leichte Drucksteigerung des Liquors $(20-40 \mathrm{~mm}$. Hg) erfolgt hauptsächlich die Vermehrung der Nystagmusschläge, mit der Herabsetzung desselben aber das Zurückschlagen zum Norm wieder.

3. Die mittelmässige Drucksteigerung (70-100 mm. Hg) vermehrt auch die Zahl des Nystagmus, doch vermindert im Gegensatz dazu die Amplitude desselben, ja sogar bringt ihn in den oscilatorischen Zustand hinüber. Diese Erscheinung erholt sich aber auf die Herabsetzung vom Liquordruck.

4. Die starke Steigerung des Druckes (100-150 mm. Hg) verstärkt zum Beginn manchmal den Nystagmus vorübergehend. Doch bei maximaler Höhe desselben, wo die Pupilles sehr anffallend erweitert, Kornéalreflex erlöscht und Pupillenreaktion wesentlich verlangsamt, bis sie schliesslich aufgehoben wird, tritt der Nystagmus unausgelöst ein. Mit dem Herabsenken des Hirndruckes kehrt es sich zum normalen 
Verhältnis. In einer Periode des im Laufe der Herabsetzung des zum maximum erhöhten Druckes ist manchmal der Richtungsumschlag des Nystagmus 'beobachtet.

5. Auch erfolgt die tempolären Sperrung des Blutzirkulation zum Hirn einen Einfluss der Hirndrucksteigerung auf den Nystagmus in jeden Fälle ganz gleicherweise.

6. Der obengenannte Einfluss der Hirndrucksteigerung ist ebenfalls beim Kompensatorischen Nystagmus zu beobachten.

7. Die Wirkung der Hirndrucksteigerung auf den experimentellen Nystagmus durch Drehung und kalorischen Reiz representiert sich folgendermassen je nach dem Grade der Drucksteigerung.

8. Bei leichter oder mittelmässiger Drucksteigerung vermehrt sich ebenso die Zahl des Drehnachnystagmus wie der kalorischen Nystagmus, und bei den letzten Fälle vermindert sogar die Amplitude desselben oder manchmal bis zur oscilatorischen. Zuckungen.

9. Wenn der Druck maximal erhöht and die Labyrinth durch Drehung oder durch Kalorisierung gereizt wird, zeigen die Auge Deviation einigermassen nach der gereizten Seite bei einer Periode, wo die Pupille mittelmässig erweitert, und Kornealreflex und Pupillenreaktion noch mehr oder weniger zurückgebrieben sind. Bei den Tieren mit den maximal erweiterten Pupillen, verschwundener Kornealreflex und herabgesetzter, sogar verfallener Pupillenreaktion kommt die vestibuläre Augenreaktion nach der Reizung gar nicht zu tage.

10. Aus diesen Ergebnisse erscheint der Angriffspunkt der Wirkung von Hirndrucksteigerung auf den Nystagmus vermutlich die vestibuläre Oblongatakerne zu sein.

(Autoreferat.) 